\title{
'N ONDERSOEK NA DIE BRONNE VAN WERKSTEVREDENHEID EN WERKSTRES ONDER MIDDELVLAKBESTUURDERS IN DIE WES-KAAP
}

\author{
SC STRYDOM \\ JC MEYER \\ Departement Sielkunde \\ Universiteit van Stellenbosch
}

\begin{abstract}
The general aim of the study is to investigate the different attitudes and perceptions of middle level managers with regard to sources of job satisfaction, sources which contribute to job dissatisfaction, and to job stress. In this regard it was decided to make use of triangulation by which qualitative and quantitative research methods are used. Thematic analysis is used on the qualitative level to identify the possible sources of job satisfaction, dissatisfaction and job stress. This method is quantitatively supported by a determination of the frequencies and percentages of subject responses by means of semi structured interviews. On the qualitative level it was found that the experience of success is rated as the most important source of job satisfaction and that interpersonal relationships are the most significant source of job dissatisfaction. Finally it seems that work expectations/ demands appear to be the major source of job stress.
\end{abstract}

\section{OPSOMMING}

Die algemene doelstelling van die studie is om ondersoek in te stel na die verskillende houdings en persepsies van middelvlakbestuurders rakende werkstevredenheid, sowel as die bronne wat bydra tot werkstres en werksontevredenheid. In dié verband is besluit om van triangulasie gebruik te maak. Op die kwalitatiewe vlak word tematiese analise gebruik om potensiële bronne van werkstevredenheid, ontevredenheid en werkstres te identifiseer. Hierdie metode word verder kwantitatief ondersteun deur ' $n$ bepaling van frekwensies en persentasies van subjekte se reponse wat uit semi-gestruktureerde onderhoude verkry is. Op die kwalitatiewe vlak blyk dit dat die ervaring van sukses die grootste bron van werkstevredenheid is en dat interpersoonlike verhoudings die bron is wat die meeste bydra tot ontevredenheid. Verder blyk dit dat werksverwagtinge/-eise die grootste bron van werkstres is.

\section{SYNOPSIS}

It is of great importance to any organization to determine the factors that cause and reinforce job satisfaction, job dissatisfaction and job stress. Middle level management is responsible for the implementation of plans and programmes. They simultaneously serve as manager and supervisor, and can then be seen as the bridge between the policymakers and the staff who implement the policies.

The general aim of the study is to investigate the different attitudes and perceptions of middle level managers with regard to sources of job satisfaction and sources which contribute to job dissatisfaction and job stress. With a knowledge of these, an organization will benefit from a middle level manager who experiences job satisfaction with a minimum of job stressors. Such an organization can effectively utilise and mobilise their human resources and will be better in reaching long-term goals through a motivated and effective management team.

With regards to the study, it was decided to make use of triangulation by which quantitative and qualitative research methods are used, with the target population being all middle level managers in the Western Cape region. Thematic analysis is used on the qualitative level to identify the possible sources of job satisfaction, dissatisfaction and stress.

This method is quantitatively supported by a determination of the frequencies and percentages of subject responses by means of semistructured interviews. In the quantitative analysis, use was made of content analysis to form a number of manageable categories which would reflect the range of responses. The researcher pointed out that although they were not used in diffracting between the middle level managers, the following dependent variables were also kept in mind. Area in Western Cape where they worked, race, age, work experience, culture, income, qualifications and marital status.

Versoeke vir afskrifte moet gerig aan: JC Meyer, Departement Sielkunde,

Universiteit Stellenbosch, Privaatsak X1, Matieland, 7602
In both the qualitative and quantitative analyses, it was found that success and/or achievements are rated as the most important source of job satisfaction. Quantitative data showed however that the attainment of goals is just as an important source of job satisfaction. The same trend was not found in the qualitative data.

Financial reward was also found to be an important source of job satisfaction. The qualitative results showed however that the work itself, the conditions in which middle level managers must work, and the role of subordinates and clients, play a greater role in job satisfaction than financial rewards.

In the qualitative and quantative analysis of the sources that contribute to job dissatisfaction, conflicting results were found. The quantitative data showed interpersonal relationships to be the biggest contributing factor of job dissatisfaction. In contrast, analysis of the quantitative data found that a poor salary, internal politics and bad management practices by the superior were the main sources of job dissatisfaction. This tendency can be attributed to the supporting nature of the qualitative data.

Analysis of qualitative and quantitative data clearly showed the sources of job stress. Analysis of both found work expectations and/or work demands to be the biggest source of job stress. However, analysis of the quantitative data also showed time pressure, long work hours and work-related responsibilities to play a contributing role in the experiencing of job stress.

Daar word algemeen aanvaar, gegewe die tyd daaraan bestee, dat werk ' $n$ groot invloed het op individue se algemene lewenstevredenheid. Voorts plaas die gemeenskap meestal 'n hoë premie op die individu se beroep en wat hy in sy beroep bereik. Alhoewel werk die bron van ons finansiële sekuriteit is, kan dit ook aanleiding gee tot baie stremming en negatiewe ervarings. Dit sou vir enige organisasie van groot belang wees om die faktore te bepaal wat aanleidend is tot werkstres en werksontevredenheid, om sodoende te kan ingryp indien die organisasiedoelwitte nie effektief bereik word nie. 
Gedurende die afgelope paar dekades, tot 1994, is die SuidAfrikaanse gemeenskap gekenmerk deur 'n politieke ideologie wat verreikende gevolge vir individue, die ekonomie en die nywerheidsektor ingehou het (Vos, 1998). So is daar byvoorbeeld in die verlede algemeen aanvaar dat mans vinniger tot bestuursposisies bevorder is as dames. Die dae van alleenseggenskap deur bestuur het egter vanaf die tagtigerjare stelselmatig begin verander. Senior bestuur het aanvanklik hul tyd hoofsaaklik aan die neem van bedryfsbesluite gewy en min tyd aan nywerheidsbetrekkinge bestee (Sunter, 1987). Die politieke en ekonomiese klimaat van die vorige politieke bestel het hierdie aanname 'n gegewe gemaak. Na die 1994 verkiesing het hierdie scenario stelselmatig verander as gevolg van verskeie politieke veranderinge.

Deur wetgewing het regstellende aksie aan die orde van die dag gekom. Regstellende aksie is daarop gemik om gelyke geleenthede vir indiensneming daar te stel. Dit poog om die samestelling van ' $\mathrm{n}$ onderneming se werkerskorps in lyn te bring met die sosiale vereistes van die gemeenskap (Cronjé, Hugo, Neuland \& Van Reenen, 1996). Gevolglik is daar sedert 1996 al hoe meer vroue en/of swart werkers in bestuursposte aangestel.

Die belangrikheid en rol van bestuur kan nie genoeg beklemtoon word nie. Enige organisasie se doeltreffendheid is aangewese op bestuur wat organisatoriese en individuele behoeftes sinchroniseer om die organisatoriese doelwitte te verwesenlik (Stümke, 1995). Bestuur is dus ' $n$ proses waardeur persone in leidinggewende hoedanighede menslike en ander hulpbronne so doelmatig moontlik gebruik om bepaalde produkte en/of dienste te lewer ten einde spesifieke behoeftes te voorsien en die organisasie se doelstellings te bereik (Kroon, 1990). Elke organisasie bestaan egter uit duidelik onderskeibare bestuursvlakke. Middelvlakbestuur is verantwoordelik vir die implementering van planne en programme. Middelvlakbestuurders tree gelyktydig as bestuurder en toesighouer op en kan gevolglik as die brug tussen die beleidsbepalers en personeel wat die beleid uitvoer, gesien word (Stümke, 1995). Die ekonomiese en politieke veranderinge in die negentigs, het 'n daadwerklike invloed op die sakesektor gehad. Regstellende aksie, industriële groei, tegnologiese vooruitgang, verminderde hulpbronne, veranderde verbruikers-voorkeure en ' $\mathrm{n}$ al hoe groter opgevoede werkerskorps, noop die bestuur van organisasies om meer aanpassings te maak (Cronje et al., 1996). Die druk van verandering gekombineer met die druk vanaf die organisasie se kant, kan aanleiding gee dat werkstres ervaar word (Edwards \& Rothbard, 1999). Stres het 'n negatiewe invloed op die welstand, effektiwiteit en gesondheid van 'n bestuurder (Moss, 1981). Stres het egter ook beduidend finansiële implikasies. Ondernemings spandeer miljoene rande aan afwesigheid, omset en verlore produktiwiteit (Edwards \& Rothbard, 1999).

Dit is egter nie net werkstres wat 'n invloed het op die effektiwiteit van die bestuur nie. Dit is vir enige organisasie van groot belang om bronne te identifiseer wat aanleiding gee tot die bestuurder se werksgeluk en tevredenheid en dat hy met entoesiasme persoonlike en organisatoriese doelwitte nastreef. Die bepaling van werkstevredenheid raak al hoe belangriker in 'n omgewing waar die tradisionele organisasies kompeteer met nuwe dinamiese, innoverende ondernemings. Organisasies moet besef dat hul nie alleen die individu moet vergoed vir sy dienste nie, maar ook die geleentheid en ruimte moet skep waarbinne individuele behoeftes en verwagtinge kan realiseer (Conradie, 1990).

Alhoewel daar heelwat navorsing rakende werkstevredenheid bestaan, is die doel van die studie egter nie om in detail die verskeie aspekte van werkstevredenheid te beskryf nie, maar eerder die subjektiewe ervarings van hedendaagse middelvlakbestuurders weer te gee.

Die huidige studie kan tot voordeel van organisasies strek om die volgende redes:
- 'n organisasie kan groter voordeel trek uit 'n middelvlakbestuurder wat werkstevredenheid ervaar en ' $n$ minimum werkstressors het wat sy werksverrigting en effektiwiteit strem

- 'n organisasie kan sy menslike hulpbronne beter benut en mobiliseer indien die bronne van werkstevredenheid en werkstres duidelik is

- 'n organisasie se langtermyndoelwitte kan meer effektief bereik word met ' $n$ gemotiveerde, effektiewe bestuurspan

\section{Werkstevredenheid}

Werkstevredenheid behels die affektiewe of emosionele reaksie van ' $\mathrm{n}$ individu teenoor sekere fasette van werk en het dus te make met die positiewe emosies wat ' $\mathrm{n}$ persoon oor sy werk ervaar (Kreitner \& Kinicki, 1989).

Spector (1996) identifiseer 'n verskeidenheid van vaardighede, taak-identiteit, sinvolheid van take en terugvoer in verband met werk as bydraend tot werkstevredenheid.

Werkstevredenheid is nie so eenvoudig om te definieer nie. Schultz en Schultz (1990) maak melding van persoonlike faktore soos byvoorbeeld ouderdom, gesondheid, emosionele stabiliteit, ensovoorts. 'n Ander belangrike faktor wat in aanmerking geneem moet word, is die individu se tipe persoonlikheid. Gevolglik definieer Tokar en Subich (1997) werkstevredenheid as die kongruensie tussen ' $n$ individu se persoonlikheid en die omgewing waarin hy werk. In die huidige studie word werkstevredenheid gedefinieer as die werker se subjektiewe ervaring van sy werksomgewing en werksomstandighede. Alhoewel nie in hierdie studie bespreek nie, speel die persoonlikheidstipe van die werker, sy algemene lewensingesteldheid en omstandighede buite die werksomgewing ook ' $\mathrm{n}$ rol in 'n ondersoek na bronne van werkstevredenheid.

Uit die literatuur blyk die volgende faktore bepalend te wees by die ervaring van werkstevredenheid:

- Uitdagende take (Arnold, Robertson \& Cooper, 1991)

- Salaris (Kum, Kervin, Clarke, Reid \& Sirola, 1998)

- Bevordering (Lussier, 1993)

- Werksure (Scandura \& Lankua, 1997)

- Toesighouer/onmiddellike hoof (Lussier, 1993)

Teorieë van werkstevredenheid

Omdat die mens ' $n$ holistiese wese is, speel allerlei veranderlikes soos byvoorbeeld kognisies en emosies, omgewingsfaktore en sosio-ekonomiese status 'n rol in hoe die mens optree en reageer in sekere situasies. Dieselfde redenasie geld ook vir werkstevredenheid deurdat verskeie veranderlikes ' $n$ rol speel in die bepaling daarvan. As gevolg hiervan is daar verskeie teorieë en uitgangspunte wat poog om die bronne van werkstevredenheid te definieer. Dit is onmoontlik om aandag aan al die teoretiese uitgangspunte rakende werkstevredenheid te gee. Gevolglik is daar besluit om in die huidige studie aandag te gee aan die motiveringsteorieë (Maslow, Herzberg en Holland), sosiale leerteorie (Lawler), waardeteorie (Locke) en die gelykheidsteorie (Adams). Daar word nie in bogenoemde teorieë voorsiening gemaak vir die ouderdom van of die lewensfase waarin ' $\mathrm{n}$ werker hom bevind nie. Gevolglik is Super se Beroepsen Lewensontwikkelingsteorie ook kortliks oorweeg. Uit die literatuur is dit egter duidelik dat geen model 'n klinkklare verduideliking vir werkstevredenheid kan verskaf nie. Die teorieë moet eerder komplementêr met mekaar vergelyk word as dat 'n enkele tendens die studie lei. Alhoewel werkstevredenheid 'n individuele, subjektiewe fenomeen is, is daar tog verskeie bronne wat aanleiding gee tot hierdie ervaring. Die teorieë van werkstevredenheid verskaf ' $n$ breë verduideliking van die veranderlikes wat in gedagte gehou moet word in die studie van werkstevredenheid voordat die onderskeie bronne van werkstevredenheid ondersoek kan word.

\section{Stres}

Die term stres is afgelei van die Latynse woord stingere, wat beteken om styf te trek. 'n Ander variasie is die Franse woord 
destresse, wat beteken om onderdruk te word (Furnham, 1997; Statt, 1994). Stres is egter ' $n$ baie breër konsep. Lussier (1993) definieer stres as die emosionele en/of fisiese reaksie op omgewingsaktiwiteite of gebeurtenisse. Daar moet egter in gedagte gehou word dat stres nie noodwendig negatief ervaar word nie. Seley (1979) definieer positiewe stres as eustres. Volgens Davy, Kinicki, en Schoeck (1997) kan beide positiewe en negatiewe stressors deur emosionele en instrumentele sosiale steun beïnvloed word.

Beroepstres, daarteenoor, betrek gewoonlik die organisasie en die werker. Dit word gevolglik gedefinieer as die interaksie van werksomstandighede met werkerseienskappe wat die normale fisiologiese of psigologiese funksies van die werker verander (Rice, 1992).

Volgens Baum (1990) het stres ten minste drie belangrike betekenisse. Eerstens kan stres verwys na enige omgewingstimulus wat aanleiding gee dat 'n persoon gespanne of opgewerk voel. In dié geval is stres ekstern tot die persoon. Tweedens kan stres verwys na 'n subjektiewe respons. Dit beteken dus dat stres die interne geestelike toestand weerspieël. Laastens kan stres ook beskryf word as die liggaamlike respons van die persoon as gevolg van 'n sekere stimulus.

Volgens Leither (1991) word die intensiteit van organisatoriese stressors bepaal deur die emosionele uitputtingsvlakke van werkers, veral as daar ' $\mathrm{n}$ tekort aan organisatoriese steun is. Werkstres word gedefinieer as die psigologiese toestand wat ontstaan as gevolg van 'n wanbalans tussen mense se persepsies van eise wat aan hulle gestel word, en hul onvermoë om dit te hanteer (Cox, 1985). Parkes (1994) is van mening dat veranderlikes soos demografiese faktore, persoonlikheidsverskille, opgewassenheid, werkverwagting, voorkeure, toegewydheid, gesondheidsfaktore, oefening, vaardighede en bekwaamheid ook in die stresverhouding in ag geneem moet word.

Voordat die bronne van stres bestudeer word, moet daar in gedagte gehou word dat sommige stressors algemeen voorkom by alle tipes werk, maar dat daar ook stressors is wat eie aan spesifieke beroepe is (Narayanan, Menon \& Spector, 1999). Die klem van hierdie studie het grootliks geval op die ondersoek na algemene werkstressors.

In die huidige studie is daar na ' $\mathrm{n}$ oorsig van die deelnemers se response besluit om die bronne van werkstres in vier hoofkategorieë te verdeel, naamlik organisatoriese stressors (die breë invloed van die organisasie), werksverwante stressors (stressors wat die dag-tot-dag funksionering van die werker behels), taakverwante stressors (die invloed wat die werker se spesifieke take het) en persoonlikheidstrekke van die werker. Alhoewel slegs bogenoemde bronne van stres in die studie bespreek is, moet veranderlikes soos byvoorbeeld demografie, kwalifikasies en huwelikstatus wat ook bydraend is tot werkers se streservarings, nie uit die oog verloor word nie.

In die literatuur is die volgende organisatoriese stressors geïdentifiseer:

- onvoldoende administratiewe steun (Fontana, 1994)

- lang ure (Sparks, Cooper, Fried \& Shiron (1997)

- swak salaris (Kum, Kervin, Clarke, Reid \& Seirola, 1998)

- "red tape" en prosedures (Fontana, 1994)

- onsekerheid en onveiligheid (Fontana, 1994)

- tipe organisasie (Melin, Lundberg, Soderland en Granqvist, 1999)

Wat werksverwante stressors betref, is die volgende in die literatuur gevind:

- rolkonflik, roldubbelsinnigheid en rolverwarring (Hammer, Allen \& Grigsby, 1997)

- oorlading, onderlading (Steward \& Balling, 1996)

- onrealistiese eise (Pentti \& Uutela, 1996)

- min insae in besluitneming (Steward \& Balling, 1996)

- toesighouers (Lobban, Husted \& Farewell, 1998)
- kollegas (Burke, Greengloss \& Konarski, 1997)

- min verskeidenheid (Fontana, 1994)

- swak kommunikasie (Fontana, 1994)

- swak leierskap (Fontana, 1994)

- tegnologie (Rice, 1992)

- interpersoonlike konflik (Narayanan et al., 1999)

Die taakverwante stressors is soos volg:

- verantwoordelikheid (Statt, 1994)

- interaksie tussen kliënte en ondergeskiktes (Fontana, 1994)

- onduidelike take (Hackman, Hoffman, Moos, Osipow \& Tornatzky, 1986)

Navorsing het egter ook getoon dat sekere persoonlikheidstrekke 'n groter predisposisie ten opsigte van die negatiewe effekte van stres het. Die tipe A-persoonlikheid word gedefinieer as ' $n$ aantal korrelerende gedragspatrone wat ongeduld, noodsaaklikheid van tyd, kompetisie en strewe na prestasie tot gevolg het (Lussier, 1993). Uit studies van Mudrack (1999) is gevind dat die Tipe A-persoonlikheid uit twee onafhanklike komponente bestaan. Die eerste bestaan uit hardwerkende, kompeterende en prestasie-georiënteerde gedrag, terwyl die ander ' $n$ geneigdheid tot ongeduld, irritasie, frustrasie en aggressie weerspieël.

Soos dit uit die literatuur blyk, is stres nie net ' $\mathrm{n}$ uitkoms nie, maar ' $n$ proses wat interaksioneel van aard is. Meer kontemporêre veranderlikes soos byvoorbeeld rassisme, korrupsie, nepotisme, verskille in kulturele waardes en regstellende aksie, begin ook stelselmatig ' $n$ belangriker rol speel in die ervaring van stres. Alhoewel die studie gefokus is op die Wes-Kaap, sal bogenoemde veranderlikes in enige provinsie van die land waargeneem kan word. In die literatuur is daar egter nog nie baie melding gemaak van hierdie veranderlikes nie, maar dit word geantisipeer dat dit in die vervolg meer na vore sal tree.

\section{Modelle van stres}

Volgens Kahn en Byosiere (aangehaal in Christie \& Schultz, 1998 ) bestaan alle stresmodelle uit ' $n$ basiese proses of patroon, naamlik ' $n$ stimulus wat ' $n$ psigologiese respons aktiveer met ' $n$ komplekse aantal gevolge in wat die welstand van die individu bepaal. Dit blyk ook dat daar algemene ooreenstemming is dat faktore soos die beskikbaarheid van hulpbronne en die individuele karaktertrekke van die werker bydra tot die strespatroon en die teenreaksie.

Landy (1989) gaan van die standpunt uit dat daar nie een algemene aanvaarde stresteorie is nie, maar eerder ' $n$ aantal pogings om stres te verstaan. Bee (1996) is van mening dat daar in effek drie kategorieë of definisies van stres is wat aan die navorser 'n konseptuele raamwerk verskaf. Die teorieë van stres kan soos volg ingedeel word:

- stimulusmodelle van stres

- responsmodelle van stres

- transaksionele modelle van stres

In hierdie navorsing het dit geblyk dat veral die stimulus- en responsmodelle van toepassing was.

\section{METODE}

Steekproefgrootte

Die belangrikste kriteria in die bepaling van die steekproefgrootte is dat die navorser seker moet maak dat die steekproef totaal verteenwoordigend is van die populasie (Martins, Loubser \& Van Wyk, 1996). Die navorser vind gewoonlik 'n kompromie tussen die bronne beskikbaar en die behoefte aan statisties betroubare resultate. Hoe groter die steekproef, hoe groter is die kans op betroubare resultate, maar hoe hoër is die koste daaraan verbonde. Allen en Skinner (1991) is van mening dat die meeste navorsers van die grootste 
moontlike steekproef wat geld en tyd toelaat, gebruik sal maak. In die huidige studie is besluit om gebruik te maak van gerieflikheidsmonsterneming.

\section{Teikenpopulasie}

In die geval van die huidige studie is die populasie alle middelvlakbestuurders in die Wes-Kaap. Die element sal enige manlike of vroulike middelvlakbestuurder ongeag ras, ouderom of kultuur wees. Die studie is gedurende 1998 gedoen en die geografiese dekking is die Wes-Kaap.

\section{Afhanklike veranderlikes}

Daar was verskeie veranderlikes wat 'n invloed op die resultate kon hê.

\section{- Area}

Onderhoude is slegs met middelvlakbestuurders in die Boland en Kaapse Skiereiland gevoer. Daar moes egter in gedagte gehou word dat die areas in bogenoemde streke verskil. Sommige van die middelvlakbestuurders kom uit historiesagtergestelde gemeenskappe. Hul ervaringsvelde sal dus verskil van diegene wat sogenaamde histories-bevoordeelde gemeenskappe verteenwoordig.

\section{- Ras}

Alhoewel die Suid-Afrikaanse samelewing al vanaf 1994 bekend is met regstellende aksie, bestaan die moontlikheid steeds dat duisende histories-agtergesteldes steeds nie hul regmatige posisies in die besigheidsektor ingeneem het nie. Middelvlakbestuurders wat ' $\mathrm{n}$ geskiedenis van bevoorregting het, se waardes, opinies en houdings mag moontlik verskil van middelvlakbestuurders wat hul slegs die afgelope 4 jaar in meer bevoorregte posisies bevind.

\section{- Ouderdom}

Gegewe die titel "middelvlakbestuurder" en nie junior of senior bestuurder nie, sou die normale verwagting wees dat die meeste van hulle ongeveer tussen 30 en 45 jaar oud sal wees. Jonger middelvlakbestuurders se ervarings van stres kan byvoorbeeld verskil van dié van ouer middelvlakbestuurders omdat die werk vir eersgenoemde nuut kan wees en hulle derhalwe nie volkome in beheer van die situasie voel nie.

\section{- Ervaring}

Die werkstevredenheid en werkstres van ' $n$ middelvlakbestuurder met min of weinig ervaring, sal beduidend verskil van 'n persoon wat al jare ' $n$ sekere pos beklee. Weinig ervaring kan aanleiding gee tot gevoelens van onsekerheid en spanning, hoewel ' $n$ persoon met jare se ervaring moontlik ander vrese en frustrasies beleef.

\section{- Kultuur}

Verskillende kultuurgroepe se ervarings in die sosiale- en beroepsomgewings gaan van mekaar verskil. Kultuurgebruike verskil onderling en die manier hoe met toesighouers en ondergeskiktes omgegaan word, kan ook verskil.

\section{- Inkomste}

Middelvlakbestuurders wat ' $\mathrm{n}$ inkomste verdien waarmee hul begroting maandeliks net klop, se behoeftes sal verskil van diegene wat uitsonderlike byvoordele en 'n hoë salaris verdien.

\section{- Kwalifikasies}

Middelvlakbestuurders wat oor tersiêre kwalifikasies beskik, se kennis strek verder as net die betrokke beroep waarin hulle hul bevind. Aangesien hul verwysingsveld in baie gevalle wyer is, is dit moontlik dat hul bronne van werkstevredenheid en werkstres sal verskil van ander middelvlakbestuurders wat nie oor soortgelyke akademiese kwalifikasies beskik nie.

\section{- Huwelikstaat}

Ongetroudes se werkservarings verskil gewoonlik van diegene wat ' $n$ verantwoordelikheid teenoor ' $n$ eggenoot het.
Enkellopendes se eise in gesinsverband is kleiner as diegene wat ook voldoende moet voorsien in die materiële en psigososiale behoeftes van hul gesin. Werkstres en/of min werkstevredenheid kan ervaar word indien die werker laat tuiskom of gereeld moet reis. Enkellopendes kan meer ure by die werk spandeer sonder om skuldig te voel omdat ' $n$ eggenoot tuis afgeskeep word.

\section{Meetinstrumente}

In hierdie studie is triangulasie gebruik, dit wil sê dat beide kwalitatiewe en kwantitatiewe tegnieke aangewend is.

\section{Kwalitatiewe ontleding}

Daar is besluit om van semi-gestruktureerde onderhoude gebruik te maak om die inligting in te win. Die onderhoudvoerder het drie basiese vrae gevra en die subjekte is aangemoedig om uit te brei op die verskillende vrae. Response is dan in drie afdelings gekodeer, naamlik:

(a) bronne van werkstevredenheid

(b)faktore wat aanleiding gee dat die werker nie werkstevredenheid ervaar nie

(c) bronne van werkstres

Tematiese analise is gebruik om die kwalitatiewe informasie te kodeer. Volgens Boyatzis (1998), bestaan tematiese analise uit die volgende drie fases soos in Tabel 1 uiteengesit:

\section{TABel 1}

STAPPE EN FASES IN DIE GEBRUIK VAN DATA-GEÏNSPIREERDE ANALISE

\begin{tabular}{ll}
\hline Fase & Data-Geinspireerde Benadering \\
\hline I & $\begin{array}{l}\text { Besluitneming oor steekproef en ontwerp kwessies } \\
\text { Kies 'n substeekproef }\end{array}$ \\
II $\quad \begin{array}{l}\text { Verminder die roudata } \\
\text { Identifiseer temas binne die substeekproewe } \\
\text { Vergelyk temas binne die substeekproewe } \\
\text { Skep 'n kode } \\
\text { Bepaal die geldigheid }\end{array}$ \\
III $\quad$ Pas die kode op die res van die rou data toe \\
\hline
\end{tabular}

Fase I

In die geval van die data-geinspireerde metode behels die eerste stap die trek van 'n steekproef. 'n Gerieflikheidsteekproef van 29 onderhoude is tematies ontleed. Dit is verdeel in 15 onderhoude met mans en 14 onderhoude met vroue. Uit hierdie 29 onderhoude word ' $n$ substeekproef getrek wat tematies ontleed is. Daar is besluit om 5 onderhoude by beide mans en vroue te gebruik as die substeekproewe.

Fase II

Stap 1

Die roumateriaal van elke eenheid van analise word nou gelees. Elke eenheid word dan geparafraseer of opgesom. Deur hierdie proses word die informasie in die navorser se onderbewussyn geprosesseer (Boyatzis, 1998).

Stap 2

Die opsommings word nou met mekaar vergelyk om ooreenkomste tussen die substeekproewe te identifiseer. Elke substeekproef word eers onderling vergelyk. In die huidige studie is substeekproef 1,2 en 3 van die mans met mekaar vergelyk en substeekproef 4 en 5 van die mans is met mekaar vergelyk. Dieselfde prosedure is by die vroue gevolg. Die doel van die vergelyking was om patrone en ooreenkomste tussen die substeekproewe te identifiseer.

Stap 3

In hierdie stap is die temas wat binne die substeekproewe geïdentifiseer is, vergelyk met die ander substeekproef se temas. Dit het impliseer dat die temas wat in die substeekproef van die 
mans geïdentifiseer is, vergelyk is met die temas wat by die substeekproef van die vroue geidentifiseer is. Die doel van hierdie stap was om die roudata in kleiner, hanteerbare pakette te plaas (Boyatzis, 1998).

\section{Stap 4}

Die navorser het vervolgens die konstruk geskryf om die twee groepe of substeekproewe te onderskei. Hierdie voorlopige temas wat geïdentifiseer is, staan bekend as 'n kode.

Stap 5

Die kode of temas is vervolgens op die res van die steekproef toegepas.

Fase III:

Die kode is op die hele steekproef toegepas.

\section{RESULTATE}

Nadat die verskillende kodes vir bronne van werkstevredenheid, bronne wat bydra dat werkstevredenheid nie ervaar word nie en bronne van werkstres geïdentifiseer is, is die kodes toegepas op die oorblywende 19 steekproef-onderhoude. Die verkreë resultate word in Tabel 2 verstrek.

TABel 2

AANTAL RESPONSE IN KODERING VAN DIE BRONNE VAN WERKSTEVREDENHEID

\begin{tabular}{|c|c|c|c|}
\hline \multicolumn{2}{|c|}{ Kode } & \multirow{2}{*}{$\frac{\mathrm{N}}{1}$} & \multirow{2}{*}{$\frac{\%}{1.09}$} \\
\hline 1 & Persoonlikheid & & \\
\hline $2 \mathrm{a}$ & Interpersoonlike verhoudings by die werk & 5 & 5.49 \\
\hline $2 b$ & Interpersoonlike verhoudings met kliënte & 2 & 2.19 \\
\hline $2 c$ & Interpersoonlike verhoudings binne die maatskappy & 1 & 1.09 \\
\hline 3 & Toesighouer & 3 & 3.29 \\
\hline 4 & Outonomie & 4 & 4.39 \\
\hline 5 & Vergoeding & 7 & 7.69 \\
\hline 6 & Take & 2 & 2.19 \\
\hline 7 & Persoonlike lewe & 1 & 1.09 \\
\hline 8 & Persoonlike verantwoordelikheid & 4 & 4.39 \\
\hline 9 & Sukses & 14 & 15.38 \\
\hline 10 & Ondergeskiktes & 8 & 8.79 \\
\hline 11 & Erkenning & 3 & 3.29 \\
\hline 12 & Persoonlike groei & 3 & 3.29 \\
\hline 13 & Werksomstandighede & 11 & 12.08 \\
\hline 14 & Maatskappybeleid & 1 & 1.09 \\
\hline 15 & Werk self & 13 & 14.28 \\
\hline \multirow[t]{2}{*}{16} & Kliënte & 8 & 8.79 \\
\hline & $\mathrm{N}=$ & 91 & 100 \\
\hline
\end{tabular}

Uit Tabel 2 blyk dit dat die beduidendste bronne van werkstevredenheid is: sukses (15.38\%); die werk self (14.28\%); die werksomstandighede (12.08\%); ondergeskiktes en kliënte $(8.79 \%)$ en vergoeding $(7.69 \%)$.

Die data oor die bronne vir ' $\mathrm{n}$ gebrek aan werkstevredenheid verkyn in Tabel 3.
TABEL 3

Aantal Response in Kodering VAN diE bronNe WAT AANLEIDING GEE DAT WERKSTEVREDENHEID NIE ERVAAR WORD NIE

\begin{tabular}{llrr}
\hline Kode & $\mathrm{N}$ & $\%$ \\
\hline 1 & Rolkonflik & 1 & 1.81 \\
2 & Ondergeskiktes & 7 & 12.72 \\
3 & Take & 3 & 5.45 \\
4 & Spertye & 2 & 3.63 \\
5 & Rasionalisering & 1 & 1.81 \\
6 & Maatskappybeleid & 2 & 3.63 \\
7 & Toesighouer & 1 & 1.81 \\
8 & Werksomstandighede & 5 & 9.09 \\
9 & Werkseise/verwagtinge & 7 & 12.72 \\
10 & Persoonlike groei & 3 & 5.45 \\
11 & Interpersoonlike verhoudings & 11 & 20.00 \\
12 & Vergoeding & 5 & 9.09 \\
13 & Tegnologiese foute & 5 & 1.81 \\
14 & Werksure & 1 & 5.45 \\
15 & Bestuur & 3 & 5.45 \\
& & 3 & 100 \\
\hline
\end{tabular}

Die bronne wat die grootste rol speel dat werkstevredenheid nie ervaar word nie, is volgens Tabel 3 die volgende: interpersoonlike verhoudings (20.00\%); werkseise/verwagtinge en ondergeskiktes $(12.72 \%)$ en werksomstandig-hede en vergoeding $(9.09 \%)$.

In Tabel 4 word die response ten opsigte van werkstres gerapporteer.

TABEL 4

Aantal ReSPONSE IN KODERING VAN DIE BRONNE VAN WERKSTRES

\begin{tabular}{llcr}
\hline Kode & $\mathrm{N}$ & $\%$ \\
\hline 1 & Maatskappybeleid & 1 & 1.31 \\
2 & Rolkonflik & 3 & 3.94 \\
3 & Werksomstandighede & 10 & 13.15 \\
4 & Werksure & 7 & 9.21 \\
5 & Toesighouer & 5 & 6.57 \\
6 & Werkseise/verwagtinge & 24 & 31.57 \\
7 & Persoonlike verantwoordelikheid & 6 & 7.89 \\
8 & Werk self & 3 & 3.94 \\
9 & Bestuur & 2 & 2.63 \\
10 & Ondergeskiktes & 8 & 10.52 \\
11 & Interpersoonlike verhoudings & 7 & 9.21 \\
& & 76 & 100 \\
\hline
\end{tabular}

Uit Tabel 4 blyk dit dat die bronne wat aanleiding gegee het tot die meeste response by die ervaring van werkstres die volgende is: werkseise/verwagtinge (31.57\%); werksomstandighede (13.15\%); ondergeskiktes (10.52\%); inter-persoonlike verhoudings en werksure (9.21\%) en persoonlike verantwoordelikheid (7.89\%).

\section{Kwantitatiewe ontleding}

In die kwantitatiewe ontleding is daar besluit om van inhoudsanalise gebruik te maak. Die doel van inhoudsanalise is om ' $n$ beheerbare aantal kategorieë te ontwikkel wat die verskeidenheid van response sou weerspieël (Hall \& Hall, 1996). Nadat die onderskeie bronne geidentifiseer is, is dit in onderafdelings verdeel om sodoende te verhoed dat belangrike inligting verlore sou gaan. Daar is sewe bronne van werkstevredenheid geidentifiseer, nl: werk, ondergeskiktes, persoonlike houdings en opinies, kliënte, salaris, 
hoof en erkenning. In die ondersoek na bronne wat bydra dat werkstevredenheid nie ervaar word nie, is ses geïdentifiseer, nl: werk, ondergeskiktes, toesighouer, geld, persoonlike houdings en opinies en werksomstandighede. Die ses bronne wat bydra tot werkstres is: werk, ondergeskiktes, hoof, persoonlike houdings en opinies, werks-omstandighede en kliënte. Die bogenoemde bronne is deur middel van inhoudsanalise verder onderverdeel en die resultate word in Tabelle 5, 6 en 7 verstrek.

TABel 5

BRONNE VAN WERKSTEVREDENHEID: HOOGSTE GEMIDDELDE PERSENTASIE RESPONSE UIT TOTALE STEEKPROEF

\begin{tabular}{lc}
\hline Aspek & $\%$ \\
\hline Take suksesvol afgehandel & 28.88 \\
Doelwitte bereik & 27.81 \\
Vergoeding & 21.93 \\
Interpersoonlike verhoudings & 19.25 \\
Persoonlike groei & 17.11 \\
Tevrede kliënte & 16.58 \\
Werksomstandighede & 14.97 \\
Verantwoordelikheid by die werk & 14.44 \\
\hline
\end{tabular}

TABeL 6

BRONNE WAT BYDRA DAT WERKSTEVREDENHEID NIE ERVAAR WORD NIE: HOOGSTE GEMIDDELDE PERSENTASIE RESPONSE UIT TOTALE STEEKPROEF

\begin{tabular}{lc}
\hline Aspek & $\%$ \\
\hline Swak salaris & 11.76 \\
Interne politiek & 8.51 \\
Swak bestuur van toesighouer & 8.02 \\
Roetine & 7.98 \\
Oormatige werkslading & 7.45 \\
Administrasie & 7.45 \\
Ondergeskiktes wat nie voluit werk nie & 5.88 \\
Negatiewe ondergeskiktes & 5.88 \\
\hline
\end{tabular}

TABEL 7

BroNNE VAN WERKSTRES: HOOGSTE GEMIDDELDE PERSENTASIE RESPONSE UIT TOTALE STEEKPROEF

\begin{tabular}{lc}
\hline Aspek & $\%$ \\
\hline Oormatige werkslading & 28.88 \\
Tydsdruk & 22.99 \\
Lang ure & 19.25 \\
Verantwoordelikheid by die werk & 14.44 \\
Mannekragtekort & 9.63 \\
Begroting wat moet klop & 9.09 \\
Werk wat vertraag word & 8.56 \\
Ontoegewyde ondergeskiktes & 8.56 \\
Verplasing/verandering & 8.56 \\
Tegnologie wat breek & 8.02 \\
Huis en werk & 8.02 \\
\hline
\end{tabular}

\section{BESPREKING}

Bronne van werkstevredenheid

Uit die totale steekproef blyk dit dat die ervaring van sukses en/of prestasie die grootste bron van werkstevredenheid is. Hierdie resultate is in beide die kwalitatiewe en kwantitatiewe ontledings gevind. Uit die kwantitatiewe data blyk dit egter dat die bereiking van doelwitte net so ' $\mathrm{n}$ belangrike bron van werkstevredenheid is. Hierdie tendens is nie in die kwalitatiewe data waargeneem nie. Bogenoemde resultate kan verklaar word teen die agtergrond van die groot bydraende faktor wat sukses en/of prestasie tot ' $n$ individu se selfwaarde het. Die middelvlakbestuurder kan voel dat hy ' $\mathrm{n}$ sinvolle bydrae tot die onderneming lewer terwyl die erkenning van ondergeskiktes en/of bestuur hierdie gevoel van selfwaarde selfs verder kan verhoog. Baron (1985) bevestig bogenoemde deur van die standpunt uit te gaan dat werkers daarvan hou om uitgedaag te word. Hierdie resultate sluit ook aan by Maslow se behoeftehiërargie (Smither, 1988).

Die finansiële vergoeding is ook ' $\mathrm{n}$ groot bron van satisfaksie. Uit die kwalitatiewe resultate blyk dit egter dat die werk self, die werksomstandighede en die rol van ondergeskiktes en kliënte ' $n$ groter bron van werkstevredenheid as die vergoeding self is. Hierdie tendens kan toegeskryf word aan die feit dat ' $n$ veel kleiner steekproef gebruik is tydens die kwalitatiewe ontleding. Dit is dikwels die geval dat vergoeding kontroversieel is en een van die groot bepalers van werkstevredenheid én ontevredenheid is. Die meeste werkers meet hulself aan die vergoeding wat hul verdien. Siegel en Lane (1982) bevestig hierdie aanname deur te meld dat geld aan die mens se basiese behoeftes voorsien, maar dat dit ook 'n simbool van prestasie, sukses en erkenning kan wees. Kum et al., (1998) is ook verder van mening dat indien die werker tevrede is met sy salaris, dit sy werkstevredenheid kan verhoog. Myns insiens bly dit egter die organisasie se verantwoordelikheid om die vergoedingspakket deeglik met sy werkers te bespreek. Die werker behoort te verstaan wat die redes is vir die betrokke vergoeding wat hy verdien, wat bevorderingsmoontlikhede is en wat van hom verwag word om die betrokke salaris te verdien. Deursigtigheid vanaf topbestuur se kant kan heelwat bydra tot die verhoging van werkstevredenheid wat hierdie aspek betref.

Die werk self is net so ' $n$ belangrike rolspeler by die ervaring van werkstevredenheid. Die ideaal is dat elke werker daarna sal streef dat sy take by die werk sinvol moet wees en dat hy ' $n$ betekenisvolle bydrae tot sy kollegas en die organisasie sal lewer. Hoe meer die tipe werk by die werker se vermoëns, intellek, persoonlikheid en vaardighede pas, hoe groter is die kans dat die werk bydraend tot werkstevredenheid sal wees. Holland se teorie gaan dan juis van die standpunt uit dat mense in baie gevalle die suksesvolste en gelukkigste is in 'n werk wat saamval met hul persoonlikheidseienskappe (Bee, 1996). Tokar en Subich (1997) definieer werkstevredenheid verder as die kongruensie tussen 'n individu se persoonlikheid en die omgewing waarin hy werk. Wanneer die werk aan die individu die geleentheid bied om sy waardes, vermoëns en behoeftes uit te leef, verhoog dit sy werkstevredenheid (Peterson \& Smart, 1997). Spector (1996) gaan van die veronderstelling uit dat die werksomgewing ' $n$ beduidende invloed op werkstevredenheid het. Daar moet egter in gedagte gehou word dat daar nie 'n standaard-werksomgewing is wat by elke middelvlakbestuurder byval sal vind nie. Omdat die persoonlikhede en persoonlike voorkeure van individue verskil, sal sommige middelvlakbestuurders optimaal funksioneer in ' $n$ sistematiese, geordende werksomgewing, terwyl ander weer ' $n$ meer losse, informele werksomgewing sou verkies. Werksomstandighede kan dus egter as relatief gesien word by die ervaring van werkstevredenheid, omdat die betrokke middelvlakbestuurders nie die tipe werksomstandighede spesifiseer nie. Die implikasies vir ondernemings is dat die rol van persoonlikhede, vermoëns, verwagtinge en vaardighede nie geïgnoreer kan word in die werksomgewing nie.

In die kwalitatiewe resultate is gevind dat die rol van ondergeskiktes en kliënte ook bydraend is tot die ervaring van werkstevredenheid. Gelukkige en tevrede kliënte is natuurlik bydraend tot die onderneming se beeld na buite. Om met gelukkige ondergeskiktes te werk, dra by tot 'n meer ontspanne 
en heel moontlik meer produktiewe werksomgewing, wat natuurlik ook positief reflekteer op die middelvlakbestuurder. Dit is egter natuurlik ook moontlik dat die meeste middelvlakbestuurders wat hierdie bron genoem het, meer mensgeoriënteerd is en dat mense in baie opsigte belangriker as die taak self is. Hierdie betrokke tendens sal dan ook op Maslow (Kreitner \& Kinicki, 1989) se sosiale vlak van motivering plaasvind waar verhoudings met ander belangrik is vir die individu. Dit is uit die ondersoek duidelik dat dit van uiterste belang is dat organisasies bewus bly van menseverhoudings. In baie opsigte word die beeld na buite en die verhouding met kliënte oorbeklemtoon en word daar vergeet van die interne verhoudings tussen kollegas, maar ook tussen die bestuurder en sy ondergeskiktes.

Bronne wat bydra dat werkstevredenheid nie ervaar word nie In hierdie afdeling is daar teenstrydighede gevind tussen die kwalitatiewe en kwantitatiewe resultate. Nadat die kwalitatiewe resultate ontleed is, blyk dit dat interpersoonlike verhoudings die grootste bydraende faktor tot dissatisfaksie is. In teenstelling hiermee is daar in die kwantitatiewe resultate gevind dat ' $\mathrm{n}$ swak salaris, interne politiek en die swak bestuur van die hoof, die grootste bronne van dissatisfaksie is. Soos reeds vermeld, kan hierdie tendens verduidelik word na aanleiding van die ondersteunende aard van die kwalitatiewe resultate.

Soos reeds gemeld, voel ' $\mathrm{n}$ werker ook dat sy waarde gemeet word aan die finansiële vergoeding wat hy ontvang. Dit is dus natuurlik dat werkers in die meeste gevalle ontevrede sal wees met hul vergoeding indien dit swak vergelyk met hul werkslading. Baron (1985); Kum et al., (1998) en Lussier (1993) bevestig hierdie aanname dat daar al hoe meer bewyse is dat werkstevredenheid verhoog word deur die regverdigheid van die vergoedingspakket. Om hierdie probleem in die praktyk op te los, kan werkers byvoorbeeld ' $n$ voorlegging voorlê waarin hul motiveer waarom hul 'n beter vergoedingspakket verdien. Topbestuur en die onmiddellike hoofde kan dan die meriete van die aansoek oorweeg.

Omdat interpersoonlike verhoudings as ' $\mathrm{n}$ belangrike bron van werkstevredenheid uitgelig is, moet die teendeel ook aandag kry. Volgens Herzberg se teorie (Saal \& Knight, 1988), is interpersoonlike verhoudings een van die higiëne-faktore wat bydraend is tot die ervaring van werkstevredenheid. Die bestuur van maatskappye en ondernemings moet bewus bly van die interpersoonlike verhoudings onder hul werknemers en/of bestuurslede. Swak interpersoonlike verhoudings het 'n negatiewe impak op die werksgees en spangees van ' $n$ onderneming en kan op die lang duur 'n negatiewe impak op die produktiwiteitsyfers hê.

\section{Bronne van werkstres}

In hierdie afdeling is die bronne van werkstres baie duidelik. In beide die kwalitatiewe en kwantitatiewe data is gevind dat werkseise en/of werkslading die grootste bron van werkstres is. In die kwantitatiewe data is daar egter ook gevind dat tydsdruk, lang ure en die verantwoordelikhede by die werk 'n bydraende rol speel by die ervaring van werkstres.

Die vraag kan tereg gevra word of bestuur daartoe in staat is om die werkslading van hul werkers te verminder. In die huidige ekonomiese klimaat blyk dit baie moeilik te wees met beperkte fondse. Omdat die werkslading vir werkers al hoe meer raak, raak tydsdruk al hoe hoër en moet hul noodgedwonge langer ure by die werk spandeer. Bogenoemde bronne het ongelukkig ' $n$ sneeubal-effek en sal met groot omsigtigheid deur die bestuur hanteer moet word. Volgens Cooper en Payne (1988) word oorlading as een van die prominente bronne van werkstres geïdentifiseer. Hierdie aanname word ook deur Statt (1994) en Rice (1992) ondersteun. Bestuur sal verseker sinvolle streshanterings- programme in hul ondernemings moet implementeer of uitbrei. Dit kan ondersteun word deur voldoende opleiding aan werkers te verskaf met betrekking tot tydsbesteding, beplanning en prioritisering.

Dit is verstaanbaar dat verantwoordelikheid ' $n$ potensiële bron van werkstres vir ' $n$ middelvlakbestuurder kan wees. Met ' $n$ senior posisie in die organisasie en die verwagtinge en eise van topbestuur sowel as ondergeskiktes, kan werkstres ervaar word. Alhoewel die middelvlakbestuurder op Maslow se selfaktualiseringsvlak is, kan die invloed en rol van stres nie geïgnoreer word nie (Kreitner \& Kinicki, 1989). Baron (1985) bevestig die aanname dat verantwoordelikheid gepaardgaan met verhoogde stresvlakke. Hy is egter van mening dat dit veral voorkom by diegene wat direk met mense moet saamwerk, in vergelyking met ander vlakke van die organisasie. Statt (1994) het gevind dat bestuurders wat ook ' $n$ toesighoudende funksie het meer geneig is tot stres as hul kollegas met dieselfde status wat nie ' $n$ toesighoudende rol vertolk nie. Die probleem kan in die praktyk aangespreek word deur potensiële bestuurders sinvol in te lig oor hul nuwe pos en verantwoordelikhede. Opleiding kan ook verskaf word in terme van beplanning, konflikhantering en motivering. Voorts sou dit ook 'n goeie idee wees dat die bestuurder toegang tot ' $n$ mentor het wat hom met betrekking tot sy verantwoordelikhede met raad en leiding kan bystaan.

\section{Aanbevelings}

Die volgende voorstelle vir verdere navorsing word vervolgens voorgelê vir beide topbestuur en navorsers wat verder belangstel in die bronne wat aanleiding gee tot werkstevredenheid, dissatisfaksie en werkstres onder middelvlak-bestuurders.

1. 'n Identifikasie van verdere raamwerke, prosesse en riglyne vir spesifiek die studie van werkstevredenheid en werkstres in ' $n$ Suid-Afrikaanse konteks (kan meer lig werp op die ondersoek).

2. Navorsing kan poog om studies op spesifieke homogene organisasies te fokus om sodoende te klein kategorieë of lae persentasies uit te skakel. Dit kan aanleiding gee dat spesifieke data relevant sal wees vir spesifieke organisasies.

3. Navorsing in verband met werkstevredenheid en werkstres van spesifiek middelvlakbestuurders, blyk noodsaaklik te wees vir organisasies wat die verhoging van produktiwiteit en effektiwiteit as ' $n$ prioriteit daarstel. Organisasies het nodig om bewus te wees van faktore wat ' $n$ rol speel by bogenoemde fenomene. Dit is voorts noodsaaklik dat organisasies bewus sal wees van die verskillende persepsies by mans en vroue en sal vervolgens moet poog om dit deur middel van personeel- en menslike hulpbronbestuur aan te spreek.

4. Spesifieke vraelyste kan gebruik word om werkstevredenheid en werkstres te meet om sodoende die resultate meer geldig en betroubaar te maak. Kategorieë behoort van so ' $n$ aard te wees dat die beduidendheid van verskille ook statisties ontleed kan word deur byvoorbeeld Chi-kwadraat.

5. Navorsing kan in die toekoms veranderlikes soos byvoorbeeld ouderdom, ras, geslag en inkomste inkorporeer by die studie van werkstevredenheid en werkstres.

6. 'n Navorsingsontwerp kan ontwikkel word wat die komplekse verhouding kan erken wat aanleiding gee tot die persepsie van werkstevredenheid en werkstres. In die ontwerp kan daar voorsiening gemaak word vir die analise van gevoelens teenoor die werk en ander komponente van organisatoriese satisfaksie of stres vanaf die perspektief dat elke faktor deel is van ' $n$ versameling van interafhanklike veranderlikes waarvan elkeen die potensiaal het om beide oorsaak of gevolg van die ander te wees.

7. 'n Analise kan gemaak word op grond van redes waarom sekere bestuurders wat essensieel onder dieselfde werksomstandighede werk, dis-funksionele gevolge van werkstres ervaar terwyl ander daarop floreer. 


\section{VERWYSINGS}

Allen, G., \& Skinner, C. (1991). Handbook for research students in the social sciences. London: Falmer.

Arnold, J., Robertson, I.T., \& Cooper, C.L. (1991). Work Psychology: Understanding human behaviour in the workplace. London: Pitman Publishing.

Baron, R.A. (1985). Understanding human relations: A practical guide to people at work. Massachusetts: Allyn \& Bacon, Incorporated.

Baum, A. (1990). Stress, intrusive imagery, and chronic stress. Health Psychology, 9, 653-675.

Bee, H.L. (1996). The journey of adulthood (3rd ed.). Upper Saddle River: Prentice Hall.

Boyatzis, R.E. (1998). Transforming qualitative information. London: Sage Publications.

Burke, R.J., Greengloss, E., \& Konarski, R. (1997). The impact of social support on the development of burnout in teachers: Examination of a mode. Work and Stress, 11 (3), 267-278.

Conradie, F.W. (1990). ' $n$ Bedryfsielkundige ondersoek na die invloed van organisasieklimaat op werkstevredenheid in die openbare sektor. Ongepubliseerde meesterstesis, Universiteit van Stellenbosch.

Cooper, C.L., \& Payne, R. (1988). Causes, coping and consequences of stress at work. Chichester: John Wiley and Sons Ltd.

Cox, T. (1985). The nature and measurement of stress. Ergonomics, 28, 1155-1163.

Cronje, G.J. de J., Hugo, W.M.J., Neuland, E.W., \& Van Reenen, M.J. (1996). Inleiding tot die bestuurswese. Johannesburg: International Thomson Publishing.

Davy, J.A., Kinicki, A.J., \& Schoeck, L.C. (1997). Testing the mediating processes between work stressors and subjective well-being. Journal of Vocational Behavior, 50 (1), 96-100.

Edwards, J.R., \& Rothbard, N.P. (1999). Work and family stress and well-being: An examination of person-environment fit in the work and family domains. Organizational Behaviour and Human Decision Processes, 77 (2), 85-129.

Fontana, D. (1994). Managing stress. Leicester: British Psychological Society.

Furnham, A. (1997). The psychology of behaviour at work. East Sussex: Psychology Press.

Hackman, J.R., Hoffman, L.W., Moos, R.H., Osipow, S.H., \& Tornatzky, L.G. (1986). Psychology at work. Productivity, change and employment. Washington: American Psychological Association.

Hammer, L.B., Allen, E., \& Grigsby, T.D. (1997). Work-family conflict in dual-earner couples: Within-individual and crossover effects of work and family. Journal of Vocational Behaviour, 50, 185-203.

Kreitner, R., \& Kinicki, A. (1989). Organizational behavior. New York: Donnelley \& Sons Company.

Kroon, J. (1990). Algemene Bestuur (2de ed.). Pretoria: Gaum.

Kum, L., Kervin, J., Clark, K., Reid, F., \& Sirola, W. (1998). Explaining nursing turnover intent: Job satisfaction, pay satisfaction and organizational commitment? Journal of Organizational Behavior, 19, 305-320.

Landy, F.J. (1989). Psychology of work behavior. California: Brooks/Cole Publishing Company.

Leiter, M. (1991). Coping patterns as predictors of burnout. Journal of Organizational Behavior, 12, 123-144.

Lobban, R.K., Husted, J., \& Farewell, V.T. (1998). A comparison of the effect of job demanc, decision latitude, role and supervisory style in self-reported job satisfaction. Work and Stress, 12 (4), 337-350.

Lussier, R.N. (1993). Human Relations in organizations. Boston: Irwin.
Martins, J.H., Loubser, M., \& Van Wyk, H. de J. (1996). Marketing research. Pretoria: Unisa.

Melin, B., Lundberg, U., Soderlund, J., \& Granqvist, M. (1999). Psychological and physiological stress reactions of male and female assembly workers: A comparison between two different forms of work organizations. Journal of Organizational Behavior, 20, 47-61.

Moss, L. (1981). Management stress. Massachusetts: AddisonWesley Publishing Company.

Mudrack, P.E. (1999). Time structure and purpose, Type A behavior, and the protestant work ethic. Journal of Organizational Behavior, 20, 145-158.

Narayanan, L., Menon, S., \& Spector, P.E. (1999). Stress in the workplace: A comparison of gender and occupations. Journal of Organizational Behavior, 20, 63-73.

Parkes, K.R. (1994). Personality and coping as moderators of work stress processes: Models, methods and measures. Work and Stress, 8, 110-129.

Pentti, J.V., \& Uutela, A. (1996). The effect of objective job demands on registered sickness absence spells: Do personal, social and job-related resources act as moderators? Work and Stress, 10 (4), 286-290.

Peterson, C., \& Smart, R. (1997). Super's career stages and the decision to change careers. Journal of Vocational Behaviour, 51 (3) 358-374.

Rice, P.L. (1992). Stress and health (2nd ed.). Pacific Grove, CA: Brooks/Cole.

Saal, F.E., \& Knight, P.A. (1988). Industrial/Organizational Psychology: Science \& Practice. Pacific Grove: Brooks/Cole Publishing Company.

Scandura, T.A., \& Lankua, M.J. (1997). Relationship of gender, family responsibility and flexible workhours to organizational commitment and job satisfaction. Journal of Organizational Behavior, 18, 377-391.

Schultz, D.P., \& Schultz, S.E. (1990). Psychology and industry today. New York: Macmillan Publishing.

Seley, H. (1979). The Stress concept and some of its implications. In V. Hamilton and D.M. WARBURTON (Eds.), Human stress and cognition: An information processing approach (pp. 11-32). New York: Wiley.

Siegel, L., \& Lane, I.M. (1982). Personnel and organizational psychology. Illinois: Richard D. Irwin, Inc.

Smither, R.D. (1988). The psychology of work and human performance. London: Harper \& Row.

Sparks, K., Cooper, C., Fried, Y., \& Shirom, A. (1997). The effects of hours of work on health. A meta-analytic review. Journal of Occupational and Organizational Psychology, 70, 391-408.

Spector, P.E. (1996). Industrial and organizational psychology. New York: John Wiley \& Sons. Inc.

Statt, D.A. (1994). Psychology and the world of work. London: Macmillan Press.

Steward, W., \& Balling, J. (1996). Daily work stress and job performance: A mediational mode. Work and Stress, 10 (4), 336-351.

Stümke, J.J. (1995). Middelvlakbestuurs-ontwikkeling in die SuidAfrikaanse Polisiediens. Ongepubliseerde meesterstesis, Universiteit van Stellenbosch.

Sunter, C. (1987). The world and South Africa in the 90's. Cape Town: Human \& Rousseau.

Tokar, D.M., \& Subich, L.M. (1997). Relative contributions of Congnience and Personality Dimensions to Job Satisfaction. Journal of Vocational Behaviour, 50, 482-491.

Vos, H.D. (1998). An industrial psychological study of the diversity phenomenon amongst managers in selected organizations. Ongepubliseerde doktorale proefskirf, Universiteit van Stellenbosch. 